\title{
COUNTERPRESSURE FOR DYSMENORRHEA PAIN IN TEENAGERS
}

\author{
Retty Nirmala Santiasari ${ }^{1 *}$, Siska Christianingsih ${ }^{1}$ \\ ${ }^{1}$ STIKES William Booth \\ *Correspondence: \\ Retty Nirmala Santiasari \\ Email: rettynirmala@gmail.com
}

Address: STIKES William Booth, Jl. Cimanuk No.20, Darmo, Wonokromo Subdistrict, Surabaya City, East Java, Indonesia 60241

\begin{abstract}
Background: Teenager is a one of development stages in the life cycle. Female teenagers are often marked by the menstrual phase. Menstruation is often accompanied by pain or what is called dysmenorrhea. Dysmenorrhea is often experienced by female teenagers and it can interfere with the activity and ability of concentration in learning that results in a decrease in performance in school. Counterpressure can be used as a solution to overcome the problem of dysmenorrhea. The counterpressure massage technique is applying strong pressure using the heel of the hand by clenching the lumbar region where there is a uterine sensory nerve that runs with the sympathetic uterus entering the spinal cord through the thoracic nerve 10-11-12 which can increase the endorphin hormone. The purpose of this study was to analyze the effect of counterpressure massage on dysmenorrhea pain in high school students.

Objective: The purpose of this study was to analyze the effect of counterpressure massage on dysmenorrhea pain in high school students. Method: The research design used was quasi experiment (one group pre-posttest design). The location of this research was Kartika IV Senior Hight School in Surabaya. The number of respondents was 30 respondents taken by consecutive sampling technique. The instrument was using NRS observation method by Hjermstad (2011). Analysis of the data in this study was using the Wilcoxon Test with a significance level 0.05 with a significance level of 0.05 .

Result: Wilcoxon test results obtained $\mathrm{p}$ value of $0.00(\mathrm{p}<0.05)$. These results indicate that there are significant differences for dysmenorrhea pain before and after the counterpressure intervention has given.

Conclusion: Counterpressure massage techniques can reduce dysmenorrhea pain experienced by female teenagers.
\end{abstract}

Key words: Counterpressure massage, Dysmenorrhea, Female Teenagers.

\section{INTRODUCTION}

Teenager is a period where the stages of development are very fast in the life cycle. At this time, it begins with a transition from children to adulthood which is marked by physical, mental, emotional and social changes. Physical changes experienced are forms of biological changes experienced by teenagers, including menstruation in women and growth of Adam's apple in the growth of men. Menstruation process generally occurs at the age of 10 to 16 years, which is influenced by several factors including women's health, nutritional status and physical development. Menstruation is often accompanied by problems such as menstrual rhythm disorders, amenorrhea, and the presence of pain during menstruation or before menstruation is often called dysmenorrhea.

Dysmenorrhea is pain that is experienced before or when menstruation occurs, sometimes the pain that is felt can disrupt a person's activity and concentration (Tangchai, et al., 2004). This pain is 
sometimes accompanied by nausea, headaches, fainting and even affect the feelings of someone who makes someone irritable (Arif, 2003). This is due to an imbalance of the hormone progesterone in the blood, women who experience dysmenorrhea produce prostaglandins 10 times more than women who do not experience dysmenorrhea. The function of prostaglandin itself is to increase uterine contractions and if in excess levels can activate the large intestine (Ernawati, 2010).

In Indonesia the incidence of teenagers with dysmenorrhea is estimated at $64.25 \%$ which consists of $54.89 \%$ primary dysmenorrhea and $9.36 \%$ secondary. While the Central Statistics Agency data shows that teenagers amounted to 63.4 million out of a population of 237.6 million, where reproductive and sexual health issues are very important among teenagers (BPS, 2010).

Dysmenorrhea which is not immediately given an action can have an impact on the disruption of daily activities, if in teenagers it can interfere with the concentration of student learning (Putri \& Sarwinarti, 2014). Handling that can be done for dysmenorrhea is with pharmacological and non-pharmacological therapy, namely with pain management. The impact of the use of pharmacological therapy in the form of anti-pain drugs only reduces temporary pain and will have an impact on impaired liver and kidney function (Baziad et al, 2004). Nonpharmacological actions or complementary therapies are safer to use and do not cause harmful side effects to the body's organs, which can be administered in the form of massase or massage (Anurogo, 2011).

Counterpressure massage is a massage that is performed by applying continuous pressure to the patient's sacrum bone with one palm of the palm (Danuatmaja, 2014). Counterpressure is a massage that uses massage techniques with strong pressure using the heel of the hand to clench in the lumbar region where the sensory nerves of the uterus run with the sympathetic nerves of the uterus entering the spinal cord through the thoracic nerve 10-11-12 to the lumbar (Ward, et al. , 2009). This massage technique increases endorphine as a physiological painkiller. Endorphine can affect the process of impulse transmission which is interpreted as a neurotransmitter that can inhibit pain (Maryunani, 2010).

\section{METHODS}

Study Design

This research is a quantitative study with a quasi-experimental design with a pre-test and post-test design without a control group.

Setting

This research was conducted at Kartika IV Senior High School Surabaya.

\section{Research Subject}

Sampling in this study was conducted by consecutive sampling, based on inclusion criteria set by the researcher. The population involved were all Kartika IV Senior High School students, while the sample involved were 30 students who had dysmenorrhea.

\section{Instruments}

Data collection techniques were carried out using observation sheets. Pain measurement was done by NRS observation method (Hjermstad, 2011). Respondents in this study only consisted of 1 group who were given the action in the form of a counterpressure massage. This action was given to respondents who were experiencing dysmenorrhea and massage given for 30 minutes.

\section{Data Analysis}

Data analysis was divided into two, namely univariate and bivariate analysis. Univariate analysis was used to obtain descriptive data on the characteristics of respondents, whereas in bivariate analysis 
to test the results of influence and compare pre-post counterpressure tests for dysmenorrhea. To identify the effect of pre and post intervention counterpressure using Wilcoxon statistical test with a significance level of $95 \%$.

\section{Ethical Consideration}

This study has received a research permit from STIKES William Booth with license number 115/STIKES-WB/III/2019 and a research permit from Kartika IV Senior High School Surabaya with license number 003/St-B/SMA IV-3/IV?2019.

\section{RESULTS}

\section{Characteristics of Respondents}

Table 1. Distribution of Frequency of Respondents in Kartika VI Senior High School Surabaya $(n=30)$.

\begin{tabular}{llc}
\hline No. & \multicolumn{1}{c}{ Variable } & $\mathrm{n}$ \\
\hline 1. & Age & $7(23 \%)$ \\
& a. 15 years old & $23(73 \%)$ \\
& b. 16 years old & $30(100 \%)$ \\
2. & Senior High School Education &
\end{tabular}

The results of counterpressure research analysis for dysmenorrhea pain in teenagers showed results on the characteristics of respondents obtained by age 15 years as many as 7 students (23\%), and 16 years of age were 23 students (73\%). Based on the characteristics of respondents could provide information that the incidence of dysmenorrhea was mostly found in teenagers. For the characteristics of respondents based on education, that in this study involved $100 \%$ of class XI high school education.

Analysis the Effect of Counterpressure Massage on Dysmenorrhea Pain in High School Students by Using Wilcoxon Statistical Test

While the results of dysmenorrhea research before being given an intervention in the form of counterpressure involving 30 samples, with Wilcoxon test results showed that dysmenorrhea pain after being given a counterpressure massage intervention the value of $p=0.00(p<0.05)$. Table 2 explains the Wilcoxon test results.

Table 2. Analysis the effect of counterpressure massage on dysmenorrhea pain in high school students by using Wilcoxon statistical test in Kartika VI Senior High School Surabaya $(n=30)$.

\begin{tabular}{|c|c|c|c|c|c|}
\hline & \multicolumn{2}{|c|}{ Before Intervention } & \multicolumn{2}{|c|}{ After Intervention } & \multirow{2}{*}{$\begin{array}{c}p- \\
\text { value }\end{array}$} \\
\hline & Mean \pm SD & $\begin{array}{l}\text { Median } \\
(\min - \\
\max )\end{array}$ & Mean \pm SD & $\begin{array}{c}\text { Median } \\
(\min - \\
\max )\end{array}$ & \\
\hline 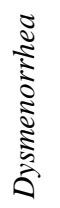 & $6.03 \pm 0.85$ & $\begin{array}{c}6.00 \\
(5-8)\end{array}$ & $2.96 \pm 1.03$ & $\begin{array}{l}3.00 \\
(2-5)\end{array}$ & $0.000^{*}$ \\
\hline
\end{tabular}

\section{DISCUSSION}

Characteristics of respondents involved in this study include age and education. The results of the study found that the most age was in the teenagers age range. Teenager is the initial process of menstruation where teenager is still looking for information related to the treatment of dysmenorrhea pain experienced. Dysmenorrhea is a pain that can affect a person's emotional status, this is very visible in teenagers who are easily offended and angry. Teenagers who experience dysmenorrhea are often difficult to control their emotions like the results of research Mou, et al (2019) which explains that teenager age is very closely related to emotional levels, so that many teenagers are found to have difficulty in controlling emotional levels. While research conducted by Chen X.C, et al (2018) explains that the age of teenagers who experience dysmenorrhea often influences attendance in school activities, so that it can influence the educational process and its activities.

Education of respondents in this study involved senior high school students. 
Senior high school students are teenage girls who often assume that menstruation is a negative experience and can affect physical and mental health; this was revealed in the results of research from Altangarvdi, et al (2019). The study also explained that psychological stress management during menstruation should be the main focus on teenagers, especially in involving health education programs in high school age or teenage girls. So that a teenager with the provision of health education they are able to overcome problems related to menstruation.

The results of the study have explained that the statistical test results on dysmenorrhea before and after being given a counterpressure intervention obtained $\mathrm{p}$ value 0.00 ( $p<0.05)$. These data indicated that there are significant differences in dysmenorrhea before and after counterpressure intervention. The results obtained in this study were supported by the results of research conducted by Vagedes, et al. (2019) entitled "Efficacy of rhythmical massage in comparison to heart rate variability of biofeedback in patients with dysmenorrhea" which explains that the administration of massage with regular pressure can provide comfort for patients with dysmenorrhea this is seen from regular pulse. In this study the massage action was not explained using massage techniques but, in that study, clearly showed that by giving regular massage to the rhythm of the massage process was able to provide a comfortable feeling for respondents who experience dysmenorrhea pain. The existence of massage is able to stimulate the release of the hormone endorphine which can function as a physiological pain reliever. As for other studies that are in accordance with the results of research that have been obtained, namely research conducted by Lee, MS., Et al (2018) explains that giving massage using aromatherapy can reduce pain in primary dysmenorrhea. Giving aromatherapy is able to create a comfortable atmosphere for someone so that with a comfortable environment and giving a massage it can increase one's comfort in dealing with the pain that is experienced. Another research conducted by Berger et al. (2019) explains that the administration of massage therapy will help change one's perception of the pain of dysmenorrhea that is experienced, which initially considered dysmenorrhea pain disrupts life for several days in each month into a harmless event in his life.

Counterpressure massage is an intervention by giving a massage that has a strong pressure using the heel of the hand that is clotted in the lumbar region to the shoulder (Ward and Shelton, 2009). The counterpressure technique is performed in the lumbal region, so it stretches the sensory nerve through the spinal cord through the thoracic nerve 10-11-12 to lumbar 1 (Santiasari, et al. 2018). This can affect the impulse of pain by blocking the area which causes the gate control to be closed which then the pain stimulus cannot be passed on to the cerebral cortex (Bobak, 2012). This action is generally used on mothers, on this occasion it can also be used on clients with dysmenorrhea where the results have shown significant differences, because the massage is able to provide stimulation to the peripheral nervous system efferent to the spinal cord to stimulate the body in the release of hormone compounds endorphine which functions as a pain reliever (Syaidah and Triani, 2011). How it works in the act of counterpressure massage is an action that works as an endogenous opiate theory, which means that opiate receptors located in the brain and spinal cord work on the central nervous system that can activate the endorphine and enkephaline hormones when pain arises. Counterpressure also stimulates the release of opiate receptors located at the peripheral sensory nerve endings, by giving a strong massage capable of blocking and increasing endorphine hormones that can relax 
muscles and relieve pain (Pratiwi \& Nurullita, 2017).

\section{CONCLUSION}

Based on the results that have been presented in this study indicated that there is an influence on the counterpressure massage interventions given to the pain of dysmenorrhea in teenagers at Kartika IV Senior High School Surabaya.

\section{SUGGESTIONS}

The results of this study can be used as a reference to overcome the pain of dysmenorrhea in teenagers, and this intervention can be carried out independently as an effort to increase knowledge for the community and can be used as an effort to develop complementary theories and practices in the field of nursing. These results can also be used as baseline data for further research relating to menstrual management.

\section{ACKNOWLEDGMENT}

Researchers would like to thank the Ministry of Research, Technology and Higher Education who gave the opportunity in the research of grants lecturer, to the chair of the STIKes William Booth who provided support and permission in conducting the Tri Dharma of higher education especially in the field of research, and did not forget to thank the headmaster of Kartika IV High School who has given permission for research in schools that he lead, respondents who have been willing to take part in activities from beginning to end, as well as to all parties who have been involved in this research.

\section{DECLARATION OF CONFLICTING INTEREST}

The complementary therapy can be implemented for pain management to deal with pain measures such as giving a compress, and pain management. Counterpressure are actions that are often done to reduce pain, but we find many of these actions to overcome labor pain (Santiasari, et al., 2018).

Therefore, researchers are interested in conducting research on counterpressure for dysmenorrhea pain. The results of this study show that there is decrease of pain in adolescents who are given the counterpressure massage.

\section{FUNDING}

This research was fully funded by the Ministry of Research, Technology and Higher Education in funding this Penelitian Dosen Pemula (PDP) in the 2019 budget.

\section{AUTHOR CONTRIBUTION}

Retty Nirmala Santiasari: A head of writer and research.

Siska Christianingsih: A member of research who help carry out this research.

\section{ORCID}

Retty Nirmala Santiasari

None.

Siska Christianingsih

None.

\section{REFERENCES}

Altangarvdi, B., Chi, H. U. A. N. G., Mengxiang, L. I. U., Jing, L. U., Huiting, P. E. N. G., Sapkota, C., \& SHENG, J. (2019). Status and factors of menstrual knowledge, attitudes, behaviors and their correlation with psychological stress in adolescent girls. Journal of pediatric and adolescent gynecology.

Anurogo, D., \& Wulandari, A. (2011). Cara jitu mengatasi nyeri haid. Yogyakarta: Andi.

Arif, Mansjoer. (2003). Kapita Selekta Kedokteran. Jakarta: Media Aesculapius.

Badan Pusat Statistik Jakarta Pusat. (2010). Statistik Indonesia Tahun 2010. Jakarta Pusat: Badan Pusat Statistik.

Baziad, A., Jacoeb, T.Z., Surjana, H. E. J., Alkaff, H. Z. (2004). Endokrinologi- 
Ginekologi Edisi Kedua. Jakarta:

Kelompok Studi Endokrinologi

Reproduksi Indonesia (KSERI)

Bekerjasama dengan Media

Aesculapius.

Berger, B., Böning, A., Martin, H., Fazeli,

A., Martin, D. D., \& Vagedes, J. (2019). Personal perception and body awareness of dysmenorrhea and the effects of rhythmical massage therapy and heart rate variability biofeedback - A qualitative study in the context of a randomized controlled trail. Complementary Therapies in Medicine.

Bobak, IM, L.D., Jensen MD, Perry SE. (2012). Buku Ajar Keperawatan Maternitas. Jakarta: EGC.

Chen, C. X., Draucker, C. B., \& Carpenter, J. S. (2018). What women say about their dysmenorrhea: a qualitative thematic analysis. BMC women's health, 18(1), 47.

Danuatmaja, B.DM. (2014). Persalinan Normal Tanpa Rasa Sakit: Puspa Swara.

Ernawati. (2010). Terapi Relaksasi terhadap Nyeri Dismenore pada Mahasiswi Universitas Muhammadiyah Semarang.

Hjermstad, M. J., Fayers, P. M., Haugen, D. F., Caraceni, A., Hanks, G. W., Loge, J. H., ... \& European Palliative Care Research Collaborative (EPCRC. (2011). Studies comparing Numerical Rating Scales, Verbal Rating Scales, and Visual Analogue Scales for assessment of pain intensity in adults: a systematic literature review. Journal of pain and symptom management, 41(6), 1073-1093.

Lee, M. S., Lee, H. W., Khalil, M., Lim, H. S., \& Lim, H. J. (2018). Aromatherapy for managing pain in primary dysmenorrhea: A systematic review of randomized placebo-controlled trials. Journal of clinical medicine, 7(11), 434.
Maryunani, A. (2010). Nyeri Dalam Persalinan. Jakarta: CV. Trans Info Media.

Mou, L., Lei, W., Chen, J., Zhang, R., Liu, K., \& Liang, X. (2019). Mediating effect of interpersonal relations on negative emotions and dysmenorrhea in female adolescents. General psychiatry, 32(1).

Pratiwi, D., \& Nurullita, U. (2017). PERBEDAAN EFEKTIFITAS TEHNIK COUNTERPRESSUREDAN KOMPRES HANGAT TERHADAP PENURUNANNYERI

PERSALINAN KALA I FASE AKTIFDI RSUD SUNAN

KALIJAGA DEMAK. Karya Ilmiah.

Santiasari, R. N., Nurdiati, D. S., Lismidiati, W., \& Saudah, N. (2018). Effectiveness of Effleurage and Counter-Pressure Massages in Reducing Labor Pain. Health Notions, 2(7), 721-724.

Syaidah, E., \& Utomo, T. Y. A. K. E. (2011). Analisis Posisi Ibu Bersalin Miring Ke Arah Ubun-Ubun Kecil Terhadap Lama Fase Aktif Kala I di Puskesmas Sukodono Sragen. Jurnal Kebidanan, 3(2).

Tangchai, K., Titapant, V., \& Boriboonhirunsarn, D. (2004). Dysmenorrhea in Thai adolescents: prevalence, impact and knowledge of treatment. Journal-medical association of thailand, 87, S69-S73. Vagedes, J., Fazeli, A., Boening, A., Helmert, E., Berger, B., \& Martin, D. (2019). Efficacy of rhythmical massage in comparison to heart rate variability biofeedback in patients with dysmenorrhea-A randomized, controlled trial. Complementary therapies in medicine, 42, 438-444.

Ward L. S. and Shekton M. H. (2009). Maternal Child Nursing Care. Philadelphia: F. A. Davis Company. 
Cite This Article As: Santiasari, R.N., \& Christianingsih, S. Counterpressure for Dysmenorrhea Pain in Teenagers. Nurse and Health: Jurnal Keperawatan 2019; 8(2): 101-107. 